\title{
The Learning Gardens Laboratory: Teaching sustainability and developing sustainable food systems through unique partnerships
}

\author{
Heather Burns, ${ }^{\text {a, } *}$ Portland State University \\ Weston Miller, ${ }^{\mathrm{b}}$ Oregon State University
}

\begin{abstract}
Submitted 28 November 2011 / Revised 3 February 2012 and 2 March 2012 / Accepted 2 March 2012 /
Published online 11 May 2012

Citation: Burns, H., \& Miller, W. (2012). The Learning Gardens Laboratory: Teaching sustainability and developing sustainable food systems through unique partnerships. Journal of Agriculture, Food Systems, and Community Development, 2(3), 69-78. http://dx.doi.org/10.5304/jafscd.2012.023.003

Copyright (C) 2012 by New Leaf Associates, Inc.
\end{abstract}

\begin{abstract}
Garden-based education programs at the Learning Gardens Laboratory (LGL) in Portland, Oregon, have been developed in a partnership between Portland State University and Oregon State University in order to advance the development of sustainable food systems and sustainability education. Learning gardens serve as rich sustainability learning sites due to their ecological and sociocultural benefits, and provide a hands-on way for

\footnotetext{
a, * Corresponding author: Heather Burns, Assistant Professor and Coordinator-Leadership for Sustainability Education; Faculty Coordinator, Learning Gardens Laboratory; Educational Leadership \& Policy, Graduate School of Education; Portland State University; P.O. Box 751; Portland OR 97207 USA; +1-503-725-8252; hburns@pdx.edu

b Weston Miller, Community and Urban Horticulturist; Coordinator, Learning Gardens Laboratory; Oregon State University Extension Service, Portland Metro Region; 200 Warner-Milne Road; Oregon City, OR 97045 USA; +1-503-706-9193; weston.miller@oregonstate.edu; http://extension.oregonstate.edu/mg/metro/
}

students to engage in interconnected issues and begin to participate in solving complex problems. At LGL there is an understanding that developing sustainable food systems also requires teaching and learning practices that reflect the goals of sustainability education. Our primary pedagogical influences are drawn from permaculture, deep ecology, ecological design, and sustainability pedagogy. A number of pedagogical principles serve as a framework for teaching sustainability holistically at LGL, including: (1) Interdisciplinary learning; (2) place-based learning; (3) active and engaged learning; (4) relationship-building; (5) multiple perspectives; and (6) systems thinking and interconnectedness. These pedagogical principles are discussed in relationship to the educational programs taking place at the Learning Gardens Lab, and we highlight two successful programs developed by our universities: the Beginning Urban Farming Apprenticeship program, and the Lane Middle School Garden-Based Education program. We also address learning that has arisen from key challenges that we face at LGL. 


\section{Keywords}

garden-based education, middle school gardenbased education, sustainability education, sustainability pedagogy, sustainable food systems, university partnerships, urban farming apprenticeship

\section{Introduction}

The sound of a chickadee calls out the hour from the bird clock on the greenhouse wall. We chuckle at this quirky reminder of the time as we wrap up our biweekly team meeting at the Learning Gardens Lab (LGL) in Portland, Oregon. At the table are faculty and graduate students from the Education and Psychology departments at Portland State University, a horticulture educator from Oregon State University (OSU) Extension Service, several Master Gardener volunteers, staff from the city of Portland's Community Gardens program, and principals from two adjacent public schools. This team represents the unique partnerships that provide the foundation of success for the Learning Gardens Laboratory, a four-acre (1.6 hectare) garden-based education site. Two universities, Portland State University (a large urban university) and Oregon State University (a large land grant university), have developed a variety of educational programs at this urban learning garden to advance the development of sustainable food systems and sustainability education. In partnership, Portland State University and Oregon State University are finding success in educating a wide range of learners in ways that cultivate relationships, a sense of place, and civic engagement for a more sustainable future.

The purpose of this article is to provide an extensive description of one example of a university-based learning garden that is rooted in partnerships. This article begins with a foundational discussion of some of the ways in which urban learning gardens serve as valuable sustainability learning sites due to their ecological and sociocultural benefits. Next, the paper describes the mission and purpose of the Learning Gardens $\mathrm{Lab}$, and the pedagogical principles that make this university partnership site a sustainability education center. We then describe the educational programs taking place at the Learning Gardens Lab and highlight two successful programs developed by our universities. Finally, we discuss some of the challenges of this garden education site, and what we have learned from these challenges.

\section{Learning Gardens and Sustainability Education}

As the rate of urbanization continues to rise and the ecological challenges of urbanization become more pressing, urban agriculture is on the forefront of sustainable solutions at many universities. University learning gardens not only contribute to the development of sustainable food systems (Gaylie, 2009), but serve as rich sites at which university students, schoolchildren, and community members can participate in sustainability education. According to Nolet (2009), sustainability education involves learning "knowledge, skills, and values that inform an individual's mental models and dayto-day behaviors. It entails more than simply knowing things about the environment, economics, or equity and justice issues, but rather involves a willingness and ability to engage intellectually and personally with the tensions that are created by the interconnectedness of these systems" (p. 421). Learning gardens ameliorate the ecological and sociocultural challenges of unsustainable urbanization in a number of integrated ways and thus provide a hands-on way to engage in interconnected sustainability issues and to begin to participate in solving complex problems.

For example, students learn how to produce and prepare locally grown organic produce, and come to understand the value and benefits of small-scale regional and urban production that can reduce some of the reliance on food that is produced at great distances from urban areas. At garden sites, learners recognize that sustainable urban farms and gardens produce less chemical pollution, and because they require less fossil energy inputs to produce and transport food, less pollution and less carbon dioxide emissions are produced overall (Pimentel, Hepperly, Hanson, Douds, \& Seidel, 2005). Learners experience and participate in what Rees (1997) refers to as "local cyclically integrated ecological production systems" (para. 3). Participating in integrated ecological systems promotes learning about sustainability in 
ways that are systemic and place-based. Participating in an urban learning garden also creates direct spatial and psychological connection to the land that supports us. This connection is vital because as Rees (1997) notes, "to many urban dwellers, even food, that most vital of basic needs, is increasingly dissociated from its origins in the sun and soil" (para. 5). Creating ways for learners to reconnect directly to their food source is essential for developing sustainability values such as relationships and interconnectedness.

From learning garden sites, students can also learn values such as reuse, conservation, and care of the earth by experiencing how these sites benefit urban areas by reducing runoff, improving water usage and retention (Pimentel et al., 2005), and recycling organic waste material (Altieri, Companioni, Cañizares, Murphy, Rosset, Bourque, \& Nicholls, 1999). Learning may also focus on how sustainable farms and gardens can improve urban soil and water quality through careful soil management, crop rotation, and by preventing soil erosion with increased ground cover (Pimentel et al., 2005). Furthermore, sustainability concepts such as the value of diversity and interconnection can be understood by examining how sustainable urban farms and gardens help to augment biodiversity both below and above the ground, resulting in increased microbial activity and respiration of soil, and more habitat for seed dispersers and pollinators (Pimentel et al., 2005), particularly if hedgerows and other nonfood plants are incorporated into a farm or garden site (Montri, 2005).

University learning gardens also assist students in exploring sociocultural benefits such as the development of local economic networks, community food security, and public health (Barndt, 2002; Gaylie, 2009; Lappé \& Lappé, 2002). Additionally, learners may discover how the ethnobotanical diversity that can be created through sustainable farming and gardening contributes to the revitalization of traditional cultural foods and medicinal plants, including the restoration of native plants for food and habitat (Altieri et al., 1999; Corlett, Dean, \& Grivetti, 2003). With such productive learning opportunities, it is perhaps not surprising that programs such as LGL are being developed by universities as unique locations from which to teach sustainability knowledge, skills, and values.

\section{The Learning Gardens Laboratory (LGL)}

The LGL was founded in 2005 by several faculty members from Portland State University's Leadership for Sustainability Education (LSE) program in partnership with Portland Public Schools, the city of Portland's Parks and Recreation, and Oregon State University Extension Service. From the beginning, the vision for the Learning Gardens Lab was to create a living laboratory for sustainable food systems based on the hands-on application of organic gardening. Importance was placed on developing partnerships with local schools and the local community in order to increase food security and teach sustainability in a holistic way.

The site of the LGL is unique in that it is located on a 12-acre (4.9-hectare) piece of land that has never been developed. The LGL is located on 4 acres (1.6 hectares) of this site, and utilizes this space for annual garden beds, small-scale farm plots, perennial hedgerows, an outdoor classroom, a native plant garden, and a permaculture garden with a diversity of edible fruiting shrubs and herbs. The mission of the LGL is to support academic achievement, leadership development, and a local sustainable food system by providing multicultural, interdisciplinary, intergenerational, and experiential garden-based education for public school students and their families, university students, and community members. Recognizing its unique location from which to teach sustainability knowledge, skills and values, the LGL is grounded in pedagogical principles that form the foundation of its sustainability education work. This pedagogical framework provides context for the partnerships and the educational programming that takes place at LGL.

\section{Sustainability Pedagogy at the Learning Gardens Laboratory}

Underlying all of the educational programs at LGL is an understanding that developing sustainable systems requires teaching and learning practices that reflect the goals of sustainability education. Sustainability education aims to reconnect learners to each other and the land, and to prepare learners 
to participate in positive changes for local communities and ecosystems. Sustainability pedagogy, therefore, must shift toward systemic, connective, and ecological ways of learning (Sterling, 2002) and toward problem-based and collaborative activities that focus on learning through inquiry, experience, and reflection (Moore, 2005). At LGL, our primary pedagogical influences are drawn from permaculture, deep ecology, ecological design, and sustainability pedagogy (Burns, 2011; Capra, 2003; Holmgren, 2002; Orr, 2004; Sterling, 2002).

The discussion of the following six principles provides a pedagogical framework for gardenbased education at LGL that is focused on teaching sustainability in a holistic way to create sustainable leaders and sustainable food systems. These pedagogical principles include: (1) Interdisciplinary learning; (2) place-based learning; (3) active and engaged learning; (4) relationship building; (5) multiple perspectives; and (6) systems thinking and interconnectedness.

Interdisciplinary learning is the first essential principle for learning sustainability at LGL. Sustainability pedagogy emphasizes holistic, nonfragmented, and interdisciplinary learning that reveals the relationships, patterns, and dynamics among the biological and cultural dimensions of life (Burns, 2011). Through learning that is interdisciplinary, learners come to know in ways that honor the holism of life, rather than learning to think and know in ways that are fragmented and divided (Sterling, 2002). Learning in a nonfragmented, holistic and interdisciplinary way is essential for those who are developing sustainable systems, as sustainability problems cannot be addressed by a single dimension (Second Nature, 2012). Rather, sustainability issues, like community food systems, are complex, layered, and must be addressed in an interdisciplinary way. At LGL, learning about food systems includes learning about relationships between science, math, geography, politics, economics, and cultural studies.

A key element of place-based learning at the LGL is following the seasons and ecological cycles of what is happening on site, day to day. The study of place is essential because it reeducates people in the art of living well where they are, and to be an inhabitant of a place from which an organic, reciprocal relationship with place can grow (Orr, 1992). Orr describes places as laboratories where the diversity and complexity of social and natural processes are highlighted. He argues, "Knowledge of a place - where you are and where you come from - is intertwined with knowledge of who you are. Landscape, in other words, shapes mindscape" (Orr, 1992, p. 130). Place-based education helps learners understand who they are, to value the places where they live, and thus to value themselves within that place. An ethic of care and responsibility with respect to place is key to sustainability (Burns, 2009a). Creating sustainable food systems requires that learners value their community, and the land that has the potential to sustain life in that community. In higher education, it is especially important to bring visibility to conceptual ideas, as can be done in the learning garden, highlighting our connection to the earth and each other (Gaylie, 2009). This heightened connection is important for helping learners understand how they can be involved in making sustainable change.

Active and engaged learning is another important aspect of sustainability education at LGL. Sustainability pedagogy is inherently focused on change, and making change requires engagement with one's self, with others, and with places. Within a sustainability paradigm, change is viewed as finding new ways of living and working so that human systems are in harmony and balance with ecological systems. This change requires an active and experiential learning process that will prepare students to take action for sustainable change (Burns, 2009b). Experiential and participatory learning is empowering; it not only creates a sense of ownership and responsibility, but also helps learners build the capacity and power to confront the sometimes overwhelming problems posed by sustainability issues (Serrano, 2000). When learners are actively engaged in learning new skills and gaining new knowledge, they are more likely to care about what they are learning. As learners participate in sustainable food systems at LGL, they learn skills to actively create change. They plant seeds, not only for the vegetables they will care for and 
harvest, but also for changes in the way they think about food and its value to the community.

Relationship building is another essential pedagogical principle at LGL. Learning at LGL places emphasis on building relationships between learners, and learners and educators, and between everybody and the land. Wheatley (2006) argues for the importance of this focus saying, "Relationships are not just interesting...they are all there is to reality" (p. 34). Focusing on relationships as the basis for all life and learning puts less emphasis on learning "objective facts" and focuses more on learning "dynamic patterns [that] continually change" (Capra, 1983, p. 91). Enhanced relationships among students promote a sense of community, belonging, and purpose (Lange, 2009), while an enhanced relationship with one's bioregion can lead to increased stewardship and living appropriately in that place (Berg, 2005). If this is the case, then developing sustainable food systems must emphasize relationship building and caring for the land and each other. At LGL, relationship building involves learning in small, supportive groups and learning in relationship with the land and the plants and animals on site.

Multiple perspectives are needed to understand complex sustainability problems, interpret information, and identify alternative solutions, and thus are also a key pedagogical principle at LGL. Multiple perspectives are valued within student groups, where diverse learners provide unique and underrepresented perspectives. For example, public school students from diverse cultural backgrounds are invited to share their experiences and understanding of growing and preparing food as a regular part of their garden lessons. University students gain multiple perspectives from guest speakers who share their experiences working within local food systems in various ways. Dresner and Seamans Blatner (2006) point out that problems possess multiple solutions and multiple ways to evaluate possible solutions, and so require students to engage in understanding problems from a variety of perspectives. Including a variety of less-heard perspectives, including intergenerational, multicultural, local, and ecological perspectives, is crucial to the process of understanding local sustainability issues (Second Nature, 2012) such as sustainable food systems.

Systems thinking and interconnectedness are also an essential pedagogical principle at the LGL. By learning systemically, students are able to understand and address complex sustainability problems holistically and to develop personal connections to the places in which their biological, social, and economic lives are grounded (Burns, 2011). Understanding that we, humans and nonhumans, are all connected and interrelated is critical to developing holistic systems that reflect this interconnectedness. Gaylie (2009) notes that in a garden, learning takes place in "the interchangeable dynamic between student, teacher, community, context, and unknown elements of nature" (p. 63). Developing food systems that are truly sustainable will require thinking and acting with an understanding of systems in which everything is interrelated. Students at LGL don't just learn how to grow vegetables, but come to understand the ecological cycles necessary to grow food, and the economic, social, and political systems that support or inhibit sustainable food systems.

These six pedagogical principles form the foundation of educational work at the LGL. As a leadership team, we are all continuously engaged in sustainability teaching and learning, and recognize these principles as important elements not just of garden-based pedagogy, but also of program development and management.

\section{Educational Programming at the Learning Gardens Laboratory: Overview}

The LGL seeks to be an educational resource for the local neighborhood and community. To address the needs of its diverse low-income neighborhood in which sustainable food options are very limited, the Lane Family Garden Program was developed. Graduate students from the Leadership for Sustainability Education (LSE) program at Portland State University coordinate the Lane Family Garden, a garden area that currently hosts a dozen low-income neighborhood families who are learning to grow their own food. Coordinators help families prepare land, plant seeds and starts, maintain their plot, and harvest vegetables. Each family gardener is paired with an 
Oregon State University Master Gardener mentor, who can help answer questions and provide support along the way. The teaching and learning that take place within this program are highly focused on relationship building, providing participants with opportunities to get to know each other, to work together to grow food, and to support each other's learning process. This is done through active and engaged learning opportunities, such as participatory workshops and mentoring, and through social opportunities such as potlucks, work parties, and an online forum. Educational workshops include topics such as vermiculture and cooking with harvested vegetables. By offering plots only to families in the local neighborhood, we are focusing on developing strong connections to place and community. Families who work together in the Lane Family Garden are developing deeper relationships to the place where they live by understanding what grows in this particular place and how to cultivate their own food through the seasons. They are also developing closer relationships with their neighbors, many of whom are immigrant families with their own rich history and stories of farming and gardening.

In addition to the family garden program, LGL addresses community food security by donating thousands of pounds of fresh, organic produce to the local community. University students, Master Gardeners, and other volunteers harvest produce from LGL and deliver it to local food banks and schools, where it is distributed to families who need it. Over 1,500 lbs. (680 kg) of fresh produce from LGL was donated in 2011.

The LGL also hosts an average of eight senior capstone service-learning classes per year in partnership with Portland State University. These courses include Environmental Education through a Native American Lens, Sustainable Food Systems, and Learning Gardens and Civic Affairs. Portland State University capstone courses provide opportunities for university students to participate in a culminating interdisciplinary service-learning project in partnership with a community organization. At LGL, capstone students contribute significantly to developing and maintaining the site, while learning about sustainable gardening and food systems. The capstone coordinator, a PSU graduate student in the Leadership for Sustainability Education Program, works closely with the capstone instructors and students to develop meaningful learning projects. The pedagogy at work in these courses focuses heavily on active and engaged learning, as these capstone courses are service-learning courses. Service learning, due to its participatory and experiential nature with goals of civic engagement and leadership, serves as an excellent application of sustainability pedagogy (Burns, 2009b). Service learning integrates meaningful community service with instruction and reflection, and serves to enhance both the learners and the service site. At LGL, the service learning that takes place is interdisciplinary, active, and engaged, and focuses on systemic solutions based on multiple perspectives. Capstone students work with LGL staff and community members to complete service projects, which have included the development of a new compost system, a craft and medicinal garden, educational materials, a neighborhood survey, LGL promotional brochures, and educational events. One of the capstone instructors also maintains a large garden plot at LGL where her students plant, tend, and harvest produce through the seasons, nurturing their connection to the land and to place.

In addition to these programs, Oregon State University's Extension Service provides horticulture training and mentoring for "Garden Works," which is part of the Community Transition Program through Portland Public Schools. This program offers life skills and business training for people ages 18 to 21 with a variety of physical, developmental, and learning challenges. Cut flowers such as tulips and dahlias are grown onsite, and students work with staff to arrange the flowers and deliver bouquets by bicycle to local businesses as part of a student-run microbusiness. Additionally, OSU Extension staff oversee a Master Gardener demonstration garden on site, which provides hands-on training opportunities for OSU volunteers and workshops for the general public. Both these programs rely heavily on active, engaged and interdisciplinary learning to teach gardening skills. Additionally, the importance of multiple perspectives is evident in the inclusion of learners' voices and input in the Community 
Transitions Program, where students are the driving force in making decisions about developing and running their small garden-driven business. At the Master Gardener demonstration garden, gardeners of all ages and backgrounds have a voice in both teaching and learning as they work together to grow organic produce.

Each year the LGL also hosts a number of events that serve as educational opportunities for the community at large and typically include an Earth Day Festival in April and a Harvest Festival in October. These events offer educational workshops by community experts, music, food, tours, and demonstrations. They serve as ways to bring the local community together to build relationships and to share our vision of holistic, systemic sustainability education and sustainable food systems.

\section{Highlighting Success: Beginning Urban Farming Apprenticeship Program and Lane Middle School Garden-Based Education Program}

Beyond these ongoing educational programs and events at LGL, Portland State University and Oregon State University Extension Service have found success in two innovative programs, the Beginning Urban Farming Apprenticeship Program (BUFA) and the Lane Middle School Gardenbased Education Program.

\section{Beginning Urban Farming Apprenticeship (BUFA)}

The Beginning Urban Farming Apprenticeship (BUFA) program is a partnership between OSU Extension Service and Multnomah County designed to provide in-depth and comprehensive training in urban farming and sustainable farming methods with research-based information. The overarching goal of BUFA is to empower participants to responsibly manage soil, water, human, and financial resources to grow food and other value-added products in urban and peri-urban settings as part of both for-profit businesses and community-based organizations.

This program was piloted in 2011 using the LGL site as one of our hands-on vehicles for education. Through formal classes, hands-on training, field trips, online learning, and supervised apprenticeships, BUFA prepares students to produce and market fresh vegetables, fruits, grains, cut flowers, and other value-added products using organic methods. Participants also learn the knowledge and skills needed to design, install, and manage farm and community landscape infrastructure in urban and peri-urban settings. The BUFA program builds participants' knowledge, skill base, and confidence in small-scale farming and farm business management in three ways: (1) a comprehensive curriculum in urban farming that includes classes, field trainings, field trips, and an online learning platform; (2) a supervised apprenticeship to "learn by doing" at the LGL and other sites; and (3) farm business planning using OSU's established Growing Farms: Successful Whole Farm Management Workshop Series.

Course topics for BUFA are based on university research and include soil management (including fertilizers, compost, mulch, and cover crops); intensive vegetable production using hand and small power tools; berry and fruit-tree production and edible landscaping; ecological landscape management (including native and ornamental plants); organic Integrated Pest Management (IPM), with special emphasis on weed control; farm and landscape infrastructure (including irrigation, materials choices, and installation); and farm business planning and marketing.

The pilot of the BUFA program trained 20 new urban farmers. The curriculum emphasized how small-scale organic farming relies on an understanding of systems and interconnected relationships, and apprenticeships provided farming education through active and engaged learning.

\section{Lane Middle School Garden-Based Education}

One of the longest running programs at LGL is the garden-based education program with Lane Middle School, located across the street from LGL. While garden-based education programs are becoming more popular for kindergarten-through-fifth-grade programs, fewer examples of successful middle school garden-based education programs exist. The LGL middle school garden-based education program is thus an interesting example of how garden-based education can be applied to middle 
schools. LGL Garden Educators, who are graduate students enrolled in Portland State University's Leadership for Sustainability Education Program, develop and facilitate garden-based curriculum for Lane Middle School students three days per week during the school year. Over 150 students from diverse racial, cultural, and socioeconomic backgrounds receive instruction each week. The proximity of Lane Middle School allows sixth graders to come to LGL once a week during their science periods. Garden Educators collaborate with science teachers to integrate key science concepts into the sustainability curriculum.

For the last four years, a team of researchers from Portland State University's psychology department has been conducting ongoing quantitative research about this partnership between the Leadership for Sustainability Education program (LSE) and Lane Middle School, focusing on how engaged participation at the LGL affects middle school students' motivation and achievement in school. This team has found that middle school students who are more engaged in the Learning Gardens perform better in school, (Skinner, Chi, \& the Learning-Gardens Educational Assessment Group, 2011). Additionally, students' engagement at the LGL was connected to more engagement in science and in school in general as well as to their academic self-perceptions, including a sense of relatedness to school, perceived competence, intrinsic motivation, and autonomy orientation. These findings are especially important for the students in this study, who are at risk for poor school performance due to their socioeconomic, minority, and/or immigrant status (Skinner et al., 2011). This quantitative study on garden-based education is the only one of its kind in the United States and highlights the success of LGL's sustainability pedagogy.

Lessons in the garden are guided by the seasons of the place so that students learn about natural cycles and become more connected to the place where they live. Learning takes place in small groups, which enhances relationship building and provides increased opportunities for hands-on active learning. Garden-based education is connected to science standards, but also includes learning about nutrition, cultural applications of food and gardening, writing, and systems thinking. Students are encouraged to share their own stories and understanding of food, and participate in planning, planting, growing, and harvesting food from their own garden plots, which they manage in small groups. Students learn about soil, compost, plant relationships, pollinators, and growing vegetables. When they harvest and cook what they have grown, this interconnected learning touches their lives in a most delicious way.

\section{Challenges and Key Learning}

While the LGL has enjoyed much success, it has not been without significant challenges. Several key and interrelated challenges include coordinating partnerships and managing programs with a mostly volunteer team, and the fiscal sustainability of the site. The LGL has a significant number of partnerships and ongoing garden-education programs, all of which need to be managed and require attention for ongoing development. Since the LGL university co-coordinators have a limited amount of paid time to work at this site, most of the programs rely on coordination by graduate student interns who are for the most part unpaid. The graduate student staff members ( 8 per year) have been committed, enthusiastic, and creative in their work at LGL. Still, these graduate students can typically only commit one to two years to an internship (five to 10 hours per week) while pursuing their degrees. Unpaid internships also create a financial burden for some students and limit their availability at LGL. When students graduate or move on, inevitably much of their experience and knowledge of LGL goes with them. The LGL coordinators must then recruit, hire, and train new staff who are unfamiliar with the site. Some of the issues related to these transitions have been mitigated by creating a system of overlapping positions, so that less experienced staff start out working with more experienced staff. We have also discovered that clearly differentiated job descriptions, staff training sessions, and ongoing opportunities for professional development are all important for smooth transitions. However, staff transitions and funding for staffing remains a significant challenge at LGL.

Managing multiple partnerships at LGL also means that we are always juggling multiple pro- 
grams with a variety of learning goals and a diversity of learners. In addition, we are continually sharing resources on site (e.g., greenhouse space, tools, compost, and irrigation equipment). We have learned that successful partnerships require ongoing relationship building and pathways for communication in order to avoid frustrations and to keep the garden running smoothly. Holding regular team meetings with LGL staff and site partners is one way that we have attempted to mitigate communication issues. We have learned that without these meetings, relationships sometimes become strained and communication can falter. At these meetings we get to know one another, celebrate successes and birthdays, share key learning, and discuss our challenges and the needs of the site. We actively cultivate a culture of learning from one another and coordinating our efforts, what permaculture refers to as "stacking functions." We encourage all staff and partners to engage in ongoing communication via phone and email between meetings as needed.

Fiscal sustainability has also been an ongoing issue, as the LGL partners are all public institutions with limited funding. The LGL has traditionally been supported through grants, donations, and university funding. However, as budgets get squeezed, we must continually justify our gardenbased education work and look for new funding sources. We have learned that highlighting LGL successes and building our reputation is an important aspect of our work, helping to generate goodwill and revenue. Research partnerships within the university have also been instrumental in generating fiscal support for garden-based education, as the site is increasingly seen as a laboratory for both valuable research and educational training. Lastly, we have begun developing revenuegenerating programs such as BUFA at the site that can help to offset the gaps in university and grant funding.

\section{Conclusion}

The Learning Garden Lab's variety of educational programs contribute to the development of a sustainable urban food system. Through its unique partnerships, LGL reaches schoolchildren, student entrepreneurs, aspiring farmers, neighborhood families, university students, and the general public. With our guiding principles of sustainability pedagogy, we are seeking to educate this wide range of learners in ways that encourage the development of knowledge, skills and values that contribute to a sustainable future. At the site, we are developing a culture that values holistic, interconnected, and active learning, as well as a diversity of relationships with place and each other. As we begin to shift toward sustainability teaching and learning that is inclusive and interconnected, we see the depth of understanding increasing. Although LGL is a work in progress, we are learning from our challenges.

The LGL provides of case study of how university and community partnerships can promote both sustainability education and sustainable food systems through garden-based educational programming. As more universities turn to sustainable urban agriculture programs to educate for sustainability in both theory and practice, developing both strong partnerships and integrated sustainability pedagogy will be fundamental to success. Intentionally created learning gardens can motivate and engage learners (Skinner et al., 2011), providing a promising pathway for positive change.

\section{References}

Altieri, M. A., Companioni, N., Cañizares, K., Murphy, C., Rosset, P., Bourque, M., \& Nicholls, C. I. (1999). The greening of the "barrios": Urban agriculture for food security. Agriculture and Human Values 16, 131-140. http://dx.doi.org/10.1023/A:1007545304561

Barndt, D. (2002). Tangled routes: Women, work and globalization on the tomato trail. Lanham, Maryland: Rowman \& Littlefield.

Berg, P. (2005). Finding your own bioregion. In M. Stone \& Z. Barolow (Eds.), Ecological literacy (pp. 126-134). San Francisco, California: Sierra Club Books.

Burns, H. (2009a). Skilled in sustainability: Teaching sustainability in skills-based courses. In W. Leal Filho (Ed.), Sustainability at universities: Opportunities, challenges and trends (pp. 195-206). Frankfurt: Peter Lang.

Burns, H. (2009b). Education as sustainability: An action research study of the Burns model of sustainability pedagogy (Doctoral dissertation). Retrieved from ProQuest (Publication number AAT 3391670). 
Burns, H. (2011). Teaching for transformation: (Re)Designing sustainability courses based on ecological principles. Journal of Sustainability Education, 2.

Capra, F. (1983). The turning point: Science, society and the rising culture. New York: Bantum.

Capra, F. (2003). The hidden connections: A science for sustainable living. New York: Anchor.

Corlett, J. L., Dean, E. A., \& Grivetti, L. E. (2003). Hmong gardens: Botanical diversity in an urban setting. Economic Botany 57(3), 365-379. http://dx.doi.org/10.1663/0013-0001(2003) 057\%5B0365:HGBDIA \%5D2.0.CO;2

Dresner, M., \& Seamans Blatner, J. (2006). Approaching civic responsibility using guided controversies about environmental issues. College Teaching, 54, 213-220. http://dx.doi.org/10.3200/CTCH.54.2.213-220

Gaylie, V. (2009). The Learning Garden: Ecology, teaching, and transformation. New York: Peter Lang.

Holmgren, D. (2002). Permaculture: Principles and pathways beyond sustainability. Hepburn, Australia: Holmgren Design Services.

Lange, E. (2009). Fostering a learning sanctuary for transformation in sustainability education. In J. Mezirow \& E. W. Taylor (Eds.), Transformative learning in practice (pp. 193-204). San Francisco, California: Jossey Bass.

Lappé, F. M., \& Lappé, A. (2002). Hope's edge: The next diet for a small planet. New York: Tarcher/Putnam.

Montri, A. (2005). Organic farming and biodiversity. Rodale Institute News and Research. Retrieved from http://newfarm.rodaleinstitute.org/research/ jan05/biodiversity.shtml

Moore, J. (2005). Seven recommendations for creating sustainability education at the university level. International Journal of Sustainability in Higher Education, 6(4), 326-339. http://dx.doi.org/10.1108/14676370510623829
Nolet, V. (2009). Preparing sustainability-literate teachers. Teachers College Record, 111(2), 409-442.

Orr, D. (1992). Ecological literacy. Albany, New York: State University of New York.

Orr, D. (2004). Earth in mind: On education, environment, and the human prospect. Washington, D.C.: Island Press.

Pimentel, D., Hepperly, P., Hanson, J., Douds, D., \& Seidel, R. (2005). Environmental, energetic and economic comparisons of organic and conventional farming systems. BioScience, 55(7), 573-582. http://dx.doi.org/10.1641/0006-3568(2005) 055\%5B0573:EEAECO \%5D2.0.CO;2

Rees, W. (1997). Why urban agriculture? (Notes for the IDRC Development Forum on Cities Feeding People: A Growth Industry). Vancouver, British Columbia. Retrieved from http://www.cityfarmer.org/rees.html

Second Nature. (2012) Sustainability curriculum framework (fact sheet). Retrieved from Second Nature: Education for Sustainability website: http://www.secondnature.org

Serrano, I. (2000). Learning sustainability from crisis. Convergence, 33(1), 78-101.

Skinner, E. A., Chi, U., \& The Learning-Gardens Educational Assessment Group. (2012). Intrinsic motivation and engagement as "active ingredients" in garden-based education: Examining models and measures derived from self-determination theory. Journal of Environmental Education, 43(1), 16-36. http://dx.doi.org/10.1080/00958964.2011.596856

Sterling, S. (2002). Sustainable education: Re-visioning learning and change. Devon, UK: Green Books.

Wheatley, M. (2006). Leadership and the new science. San Francisco: Berrett-Koehler. 